\title{
Fever of unknown origin - a literature review
}

\author{
(iD) Leonardo Fernandes e Santana ${ }^{1}$ \\ (iD) Mateus de Sousa Rodrigues ${ }^{1}$ \\ (iD) Marylice Pâmela de Araújo Silva² \\ (iD) Rodrigo José Videres Cordeiro de Brito ${ }^{3}$ \\ (i) Jandir Mendonça Nicacio ${ }^{4}$ \\ Dita Marina Soares de Castro Duarte \\ (iD) Orlando Vieira Gomes ${ }^{6}$
}

\begin{abstract}
1. Discente de Medicina na Universidade Federal do Vale do São Francisco (UNIVASF), Petrolina, PE, Brasil 2. Médica formada pela UNIVASF, Petrolina, PE, Brasil 3. Médico Infectologista. Professor MSC efetivo da disciplina de Infectologia da UNIVASF, Petrolina, PE, Brasil 4. Médico Hematologista. Preceptor da Residência Médica de Clínica Médica do Hospital Universitário da UNIVASF. Professor efetivo das disciplinas de Doenças hematológicas e de Oncologia da UNIVASF, Petrolina, PE, Brasil 5. Médica Reumatologista. Preceptora da Residência Médica de Clínica Médica do Hospital Universitário da UNIVASF. Professora efetiva da disciplina de Reumatologia da UNIVASF, Petrolina, PE, Brasil 6. Médico Nefrologista. Preceptor da Residência Médica de Clínica Médica do Hospital Universitário da UNIVASF. Professor MSC efetivo da disciplina de Medicina de Urgência da UNIVASF, Petrolina, PE, Brasil
\end{abstract}

http://dx.doi.org/10.1590/1806-9282.65.8.1109

\section{SUMMARY}

Fever of undetermined origin (FUO) is a challenging entity with a striking presence in hospitals around the world and can be associated with a myriad of differential diagnoses. It is defined as axillary temperature $\geq 37.8^{\circ} \mathrm{C}$ on several occasions, lasting $\geq$ three weeks, in the absence of diagnosis after three days of hospital investigation or three outpatient visits. The main etiologies are: infectious, neoplastic, and rheumatic. The diagnosis is based on the detailed clinical history and physical examination of these patients, in order to direct the specific complementary tests to be performed in each case. Empirical therapy is not recommended (with few exceptions) in patients with prolonged fever, as it may disguise and delay the diagnosis and conduct to treat the specific etiology. The prognosis encompasses mortality of $12 \%$ - 35\%, varying according to the underlying etiology. In this sense, the objective of this study is to review the main topics about fever of undetermined origin, bringing historical and scientific aspects, national and international.

KEYWORDS: Fever of Undetermined Origin; Fever of Unknown Origin; Prolonged fever.

\section{INTRODUCTION}

Fever of undetermined origin (FUO), of obscure origin, or fever without an apparent cause is a challenging clinical entity with high worldwide prevalence, and a myriad of differential diagnoses ${ }^{1-5}$. It affects all age groups, with some peculiarities at age extremes ${ }^{6,7}$. FUO presents an etiologic pattern represented by four general categories: infectious, neoplastic, non-infectious inflammatory diseases, and miscellaneous. A fifth category is considered by some authors as the idiopathic presentation of FUO, or true FUO ${ }^{1,8-10}$. Despite a large number of diagnostic resources, meticulous clinical examination is still the fundamental approach to patients with prolonged fever. Empirical therapy is performed only in selected cases, since some medications may mask symptoms and interfere with the early etiological diagnosis, 
which is necessary to specify the proper therapy in most cases ${ }^{2,11}$. The objective of this study is to review the main historical and scientific aspects of the fever of undetermined origin.

\section{METHODS}

This is a literature review carried out on the more recent publications in the PubMed Central ${ }^{\circledR}$ database. The research used the descriptor "Fever of Unknown Origin" and the secondary descriptors: "Analysis", "Complications", "Diagnosis", "Enzymology”, "Epidemiology”, "Etiology”, "Immunology”, "Metabolism”, "Microbiology”, "Mortality”, "Parasitology", "Pathology", "Physiology", "Physiopathology", "Statistics and numerical data", "Therapy", "Virology". All secondary descriptors were associated with the main descriptor using the tool "OR". A total of 3,736 results were found. Then, the following filters were applied: "Review", "Clinical Trial”, "Meta-Analysis", "Systematic Reviews", "Full text", "published in the last five years", and "Humans". After applying the filters, the results were narrowed down to 75 items. Of these, 23 articles were selected after an analysis of their summary and abstract. The Scielo database was used as a complement to include more Brazilian studies. The descriptor "Febre de origem indeterminada" was used, retrieving a total of 15 matches, which were reduced to 13 after the filters "Brasil" and "Ciências da Saúde" were applied. We did not use any filter for year of publication while selecting Brazilian articles due to the scarce scientific production/update on the subject. After analyzing the papers, five were selected based on the scope of the present study, totaling 28 references. This review was conducted in December 2017.

\section{DISCUSSION}

\section{Concept}

Fever of undetermined origin was initially characterized in 1961 by Petersdorf and Beeson as a record of oral temperature $>38.3^{\circ} \mathrm{C}$ on at least three different occasions, for a minimum of three weeks, in the absence of diagnostic hypotheses that could explain the fever after a week of investigation 1,2,12-14. The purpose of this concept was to eliminate autolimited infections and habitual hyperthermia, in addition to, at the same time, provide sufficient time for a robust diagnostic investigation ${ }^{1,8}$. One of the most accepted concepts of classical FUO encompasses axillary temperature $\geq 37.8^{\circ} \mathrm{C}$ on several occasions, for a period $\geq$ three weeks, with no diagnosis after three days of hospital investigation or three outpatient consultations ${ }^{8.15}$.

\section{Etiology and epidemiology}

Some authors defend the existence of more than 200 possible causes for FUO 1,2,16,17. The main causes are of infectious, neoplastic, and rheumatic nature. Table 1 addresses the proportion of each FUO group and identifies the infectious causes as the main causes of fever, in most of the studies ${ }^{1,8,12,18}$. Despite all clinical, laboratory, and imaging research, a portion of 7-50\% can still remain with no diagnosis (idiopathic) ${ }^{1,9,10}$. In developed countries, neoplastic and rheumatic causes are usually predominant, while in developing countries infections often prevail'. A Brazilian study ${ }^{8}$ provides the prevalence of the main etiologies of FUO in the country, in 1989 (Table 2). Infectious etiologies were the main causes of FUO in most of the studies ${ }^{17}$. Among the infectious causes, abscesses (in the pancreas, liver), endocarditis, tuberculosis, and complicated urinary tract infections (UTIs) stand out in all age groups ${ }^{1.7}$. Fever is not the most common symptom in rheumatic patients. However, some rheumatic diseases can progress with varying degrees and patterns of fever, accounting for up to $30 \%$ of FUO cases, according to some authors ${ }^{16}$. Most rheumatic cases that include FUO consists of arthritis (e.g., juvenile idiopathic arthritis), vasculitis (e.g. Kawasaki disease), systemic lupus erythematosus (SLE), and Still's disease. ${ }^{6,19-21}$

A study conducted in 1961 by Browder and collaborators reported the incidence of fever in patients with neoplasms for one year ${ }^{12}$. They found that fever was not so common in these patients (of 343 patients, $5 \%$ had fever). Fever in cancer patients can happen due to several factors, the main ones being secondary infections (etiology in $2 / 3$ of oncology patients with FUO) and obstructions caused by the tumoral mass $^{12}$. Many neoplasms can cause FUO, but the most frequent are hematological (lymphoma is the main neoplasm associated with FUO), hepatic, colonic, and pancreatic ${ }^{12,17,22}$. There are other specific potential causes for FUO that do not fit the categories of infectious, neoplastic, rheumatic and hence form the miscellaneous group. Its main representatives are factitious fever, subacute thyroiditis, and drug fever ${ }^{17}$. 


\section{Clinical history and physical examination}

Brazilian studies ${ }^{8.23}$ recommend essential precepts for the approach of patients with FUO, among which the following are particularly noteworthy: making sure that the patient actually has a fever; systematization of the clinical examination; exclusion of serious and treatable etiologies; considering the hypothesis of fever caused by medications; exclude underlying immunodepression; consider an association of diseases; good doctor-patient relationship.

\section{Clinical history}

A detailed anamnesis is the main tool for the approach of a patient with a history of prolonged fever, and it must include travel history, professional matters, home environment, housing, use of medication and illicit drugs, contact with animals and sick people ${ }^{18}$. It is always worth inquiring about symptoms that may be considered unimportant, such as jaundice, weight loss, chronic cough, and change in bowel movements, associated with the fever. The personal and family history of previous diseases can also provide valuable indications of specific etiologies (mainly autoimmune diseases) ${ }^{8}$. Up to $28 \%$ of travelers who return to their place of origin report fever as the main complaint in medical consultations ${ }^{13}$. The main etiologies in these patients, especially those who traveled to tropical countries, are: malaria (most common etiology), dengue, leptospirosis, rickettsiosis, salmonellosis, amoebiases, and schistosomiasis ${ }^{13}$. Endemic diseases should always be remembered at the time of the clinical investigation. Each FUO category presents specific details that stand out in the clinical history:

Infections: a history of invasive procedures and surgeries; search for a history of previous infections. Contact with animals must raise the suspicion of toxoplasmosis, brucellosis, cat-scratch disease, malaria, piroplasmosis, leptospirosis. Patients usually present fever associated with chills. Immunosuppressive drugs increase the risk of tuberculosis and viral infections ${ }^{2}$.

Neoplasms: Neoplasms tend to be associated with early hyporexia or anorexia and progressive weight loss².

Rheumatic: Myalgias and arthralgias suggest rheumatic etiologies. A history of oral ulcers may suggest SLE or Behcet's disease. Family history usually reveals important data ${ }^{2}$.

Miscellaneous: A history of lymphadenopathy may suggest Rosai-Dorfman or Kikuchi's disease. Neck pain can be a valuable clue for the diagnosis of thyroiditis ${ }^{2.8}$.

\section{Physical examination}

Elementary lesions on the skin, lesions in the oropharynx, teeth ${ }^{24}$ (dental abscesses), visceromegalies, lymph node enlargement, pelvic and abdominal

TABLE 1. CAUSES OF CLASSICAL FUO'. ADAPTED FROM UNGER M, KARANIKAS G, KERSCHBAUMER A, WINKLER S, ALETAHA D. FEVER OF UNKNOWN ORIGIN (FUO) REVISED. WIEN KLIN WOCHENSCHR. 2016;128(21-22):796-801.

\begin{tabular}{l|l|l|l|l|l}
\hline Author (Year) & Infectious (\%) & Neoplastic (\%) & Rheumatic (\%) & Miscellaneous (\%) & Idiopathic (\%) \\
\hline Petersdorf (1961) & 36 & 19 & 19 & 19 & 7 \\
\hline Larson (1982) & 30 & 31 & 16 & 11 & 12 \\
\hline Knockaert (1992) & 22.5 & 7 & 23 & 21.5 & 26 \\
\hline De Kleijin (1997) & 26 & 12 & 25 & 8 & 30 \\
\hline Bleeker-Rovers (2007) & 16 & 7 & 22 & 4 & 51 \\
\hline
\end{tabular}

TABLE 2. MAIN CAUSES OF CLASSICAL FUO IN A STUDY CONDUCTED IN BRASIL (1989), ON 54 PATIENTS8. ADAPTED FROM LAMBERTUCCI JR, ÁVILA RED, VOIETA I. FEBRE DE ORIGEM INDETERMINADA EM ADULTOS

\begin{tabular}{|c|c|c|c|c|}
\hline Infectious (43\%) & Neoplastic (17\%) & Rheumatic (17\%) & Miscellaneous (19\%) & Idiopathic (8\%) \\
\hline $\begin{array}{l}\text { Tuberculosis } \\
\text { Endocarditis } \\
\text { Abscess } \\
\text { Malaria } \\
\text { Toxoplasmosis } \\
\text { Gonococcal perihepatitis } \\
\text { Salmonellosis } \\
\text { Schistosomiasis } \\
\text { Katayama fever }\end{array}$ & $\begin{array}{l}\text { Hodgkin's disease } \\
\text { Adenocarcinoma } \\
\text { Metastasis } \\
\text { Leukemias }\end{array}$ & $\begin{array}{l}\text { Systemic Lupus Erythe- } \\
\text { matosus (SLE) } \\
\text { Still's disease } \\
\text { Giant cell arteritis } \\
\text { Polymyalgia rheumatica }\end{array}$ & $\begin{array}{l}\text { Subacute thyroiditis } \\
\text { Granulomatous hepatitis }\end{array}$ & \\
\hline
\end{tabular}


FIGURE 1. ALGORITHM PROPOSED FOR THE DIAGNOSTIC APPROACH TO PATIENTS WITH FUO. ADAPTATION AUTHORIZED BY UNGER M, KARANIKAS G, KERSCHBAUMER A, WINKLER S, ALETAHA D. FEVER OF UNKNOWN ORIGIN (FUO) REVISED. WIEN KLIN WOCHENSCHR. 2016;128(21-22):796-801.

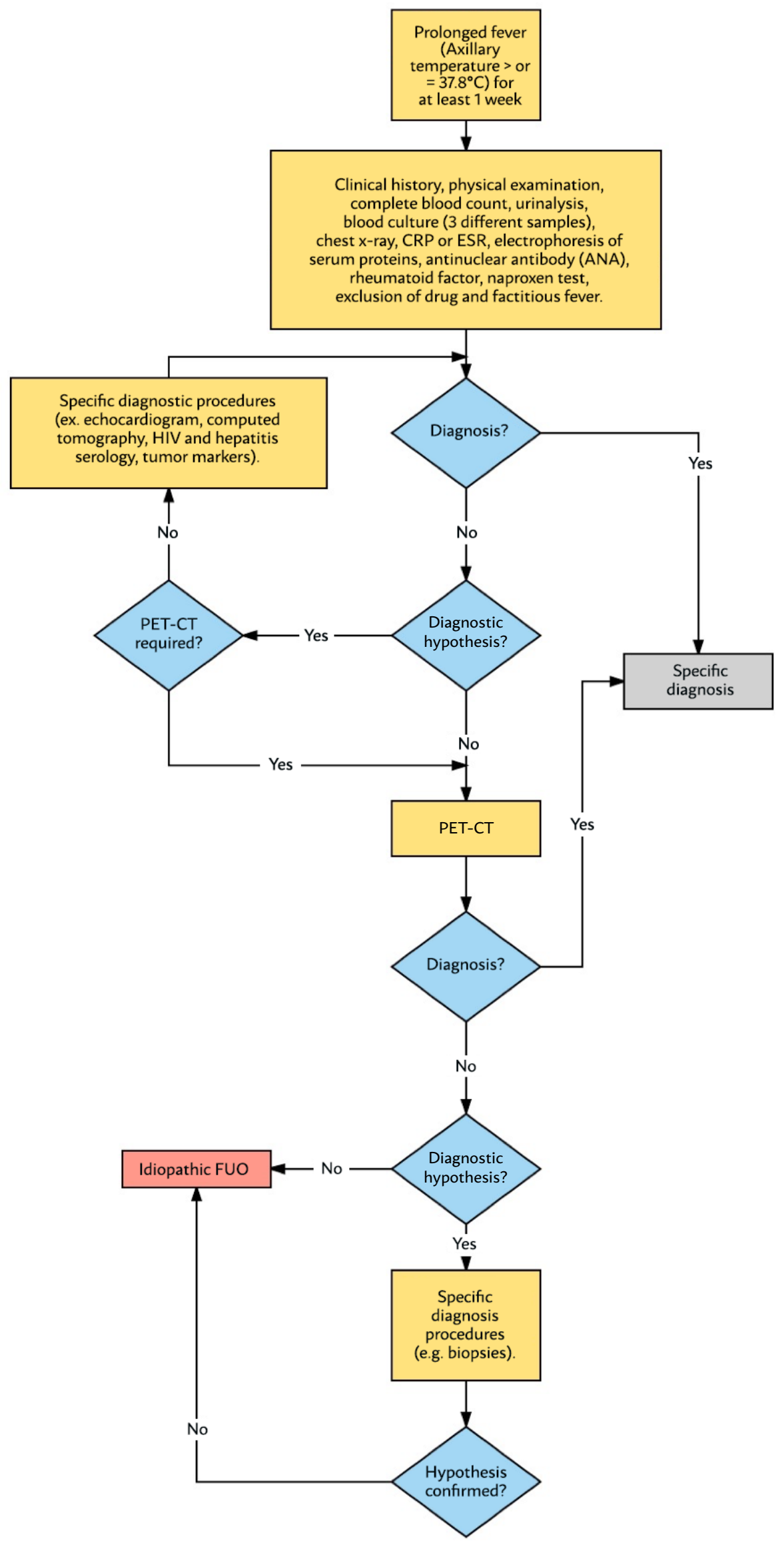


masses or heart murmurs ${ }^{2}$. Fundoscopy and anoscopy must be performed whenever possible. Ideally, the thermal curve must be obtained so that it can be associated or not with the classic patterns of some etiologies (malaria, tuberculosis, for example) ${ }^{8}$.

Infections: FUO with morning peaks can be an indication of typhoid fever and Whipple's disease. The Faget sign suggests entities such as yellow fever or typhoid fever. Two peaks of fever per day can be indicative of malaria, miliary tuberculosis, or visceral leishmaniasis (which may also present a single peak in the afternoon) $)^{2}$. Roth spots observed during fundoscopy should raise a suspicion of infectious endocarditis. Q fever is an important differential diagnosis in cases of isolated hepatomegaly ${ }^{2}$.

Neoplasms: malignancies of the central nervous system or lymphomas can cause bradycardia. Retinal hemorrhages can suggest pre-leukemia. Isolated hepatomegaly in cases of FUO can be suggestive of hepatic or kidney neoplasias, or metastasis².

Rheumatic diseases: fever with morning peaks reinforce the hypothesis of polyarteritis nodosa. Two daily peaks raise suspicion of Still's disease. Differences between the pulses and the arterial pressure of the limbs are important findings in the diagnosis of Takayasu arteritis. The presence of oral ulcers may suggest SLE or Behcet's disease. Lymphadenopathy is a finding that may be present in SLE, sarcoidosis, or rheumatoid arthritis. Libman-Sacks endocarditis should be remembered in patients with SLE and new heart murmurs ${ }^{2}$.

Miscellaneous: the patient has few clinical signs in addition to the fever. The causes of this group depend much more on clinical history than the physical examination ${ }^{2}$.

\section{DIAGNOSIS}

The diagnosis must be based on the clinical history and thorough physical examination of these patients, with the purpose of establishing specific complementary exams for each case $e^{2,15,18}$. There is no consensus on the optimal diagnostic approach for a patient with $\mathrm{FUO}^{2}$. However, there are several protocols and algorithms that can be used to facilitate the diagnostic investigation of prolonged fever. The most current include more sophisticated tests, such as Positron Emission Computed Tomography (PET-CT). Figure 1 presents an adaptation of a current algorithm for the diagnostic approach of prolonged fever. It should be emphasized that all approaches should be based on the patient's clinical context, since it may not be feasible to perform a large number of exams. The physician must select the exams that can confirm or exclude common nosological entities, always taking into account the local epidemiology. The initial approach must include nonspecific tests ${ }^{2}$. If no diagnostic hypothesis is raised from the nonspecific tests, a series of more specific tests should be performed (serology for hepatitis, biopsies, cultures for mycobacteria, echocardiogram, CT of the abdomen and chest $)^{11}$.

\section{Naproxen test}

The naproxen test can be useful in the differential diagnosis of FUO, although there is controversy among some authors ${ }^{2.8}$. The test is based on the answer to the empirical therapy with naproxen in patients with prolonged fever (for at least seven days). An etiology of infectious nature should be suspected in patients with no response to the empirical treatment, while in case of a response to the test in 24 hours a neoplasm should be suspected as the cause for the fever'.

\section{Laboratory tests}

Nonspecific laboratory investigation in the initial approach to a FUO patient can make it easier to identify the underlying etiology, based on the most likely diagnostic hypotheses, suspected from the clinical examination data ${ }^{11}$. The first line exams are: complete blood count, C-reactive protein (CRP), erythrocyte sedimentation rate (ESR), serum creatinine, electrolytes, markers of liver function, rheumatoid factor, antinuclear antibodies, electrophoresis of serum proteins, and blood cultures (three samples of different punctures) $)^{11}$. The second line exams should be based on the suspected diagnosis provided by clinical examination and the first line exams, they include: serology for human immunodeficiency virus (HIV), serum ferritin, thyroid function, lactic dehydrogenase, serology for specific agents, bacilloscopy, echocardiogram, among others ${ }^{11}$. More specific and/or invasive tests are the next steps in the investigation of the etiology of FUO when the preceding steps are not sufficient (e.g. biopsies). There is a recommendation to perform bone marrow biopsies, even in the absence of changes in peripheral blood ${ }^{8}$.

Blood cultures are useful in cases of bacteremia as the etiology of FUO, for example, in brucellosis, typhoid fever, and in some abscesses. It can be dismissed in cases of low clinical probability of 
infectious etiologies for the FUO, such as in neoplasms and rheumatic diseases ${ }^{2}$. The complete blood count is very important and should be requested in virtually all cases. Very often, it shows data that should be valued, such as leukopenia, eosinophilia, lymphocytosis, thrombocytosis, anemias, and thrombocytopenias ${ }^{2}$. In FUO patients, isolated and elevated alkaline phosphatase can be an indication of lymphoma ${ }^{2}$. CRP and ESR are important evidence of inflammatory activity in the follow-up of FUO patients. Serum protein electrophoresis can provide valuable data: elevation of the alpha-1/ alpha-2 globulin ratios may occur in lymphomas and in SLE; monoclonal gammopathy can suggest multiple myeloma, hyper-IgD syndrome, Castleman disease; polyclonal gammopathy may be indicative of infection by the human immunodeficiency virus, cytomegalovirus, also occurring in the presence of cirrhosis, sarcoidosis, and malaria ${ }^{2}$. The urinalysis is key in the initial approach to FUO patients, especially those with vague clinical examination. Microhematuria may be the first or sole indication of subacute endocarditis, renal tuberculosis, polyarteritis nodosa, brucellosis, or renal neoplasms ${ }^{2}$. The antinuclear antibody (ANA) test is valuable in suspected rheumatic etiologies of FUO and may assist the diagnosis in $2-12 \%$ of cases ${ }^{15}$.

\section{Imaging exams}

It is essential that the radiologist is familiar with the case of each patient. In general, the first exams requested are cheaper and less specific, such as radiographs and ultrasound. When the first tests are inconclusive, more specific tests such as computed tomography (CT) and nuclear magnetic resonance (NMR) can be requested ${ }^{17}$. Masses, cavitary effusion, consolidations, abscesses, adenopathies, and visceromegalies are some of the main findings of imaging examinations ${ }^{17}$. CT is of extreme value in the diagnosis of tuberculosis and lymphoproliferative diseases, as well as in the staging of neoplasms. NMR may be vital in cases of central nervous system, pelvic, and vertebral diseases. ${ }^{17}$

A number of studies have been conducted in recent years to evaluate the role of PET-CT, which remains controversial for some authors when taking into account the cost in its applicability, 5,917,25-27. Some authors defend the PET-CT as a first line exam in the approach for $\mathrm{FUO}^{28}$. A recent study involving 52 FUO patients recorded that PET-CT was performed in 22 patients, successfully identifying inflammatory, infectious, and neoplastic causes in 10 of the 22 patients. The positive predictive value was $83 \%$, and the negative predictive value was $50 \%^{12}$. This imaging method makes it easier to precisely identify the location of neoplastic and inflammatory lesions, but its cost is still high, so it should not be used routinely ${ }^{11.18}$. The sensitivity of the PET-CT for the diagnosis of non-infectious inflammatory diseases is $65 \%{ }^{15}$.

\section{TREATMENT}

In general, empirical therapy is not recommended for patients with prolonged fever, since it can mask and delay the diagnosis and the management of the specific etiology ${ }^{11}$. Some exceptions to this rule are suspected diagnosis of: infective endocarditis with a negative culture (empirical antibiotic therapy is indicated), active tuberculosis (the empirical use of tuberculostatics is indicated), as well as temporal arteritis with a risk of loss of vision (empirical corticosteroid therapy is indicated). Glucocorticoids should be used with caution and in selected cases'. The use of antipyretics for symptomatic relief may be necessary in cases in which the patient does not tolerate the fever or febrile peaks. It is important to emphasize that the fever pattern is important for the diagnosis of the underlying etiology and that the antipyretics may distort that finding 1,2,11.

\section{PROGNOSIS}

Despite all the current diagnostic and therapeutic tools, the mortality rate for FUO remains around $12-35 \%{ }^{1.8}$. This variation is justified by the different etiologies associated with FUO. However, the group that remains without a definite diagnosis (idiopathic FUO) presents a good prognosis, usually with the cessation of the fever after four weeks or more, with mortality of $3.2 \%$ in five years. Records show that $51-100 \%$ of these patients can recover spontaneously ${ }^{1}$. The greater mortality in patients with FUO is represented by neoplastic etiologies ${ }^{16}$. 


\section{RESUMO}

Febre de origem indeterminada (FOI) é uma entidade desafiadora com presença marcante nos hospitais de todo o mundo, à qual uma miríade de diagnósticos diferenciais podem estar associados. É definida como temperatura axilar $\geq 37,8^{\circ} \mathrm{C}$ em várias ocasiões, com duração $\geq$ três semanas, na ausência de diagnóstico após três dias de investigação hospitalar ou três consultas ambulatoriais. As principais etiologias são de ordem infecciosa, neoplásica e reumatológica. O diagnóstico é baseado na história clínica e no exame físico minuciosos desses pacientes, com a finalidade de direcionar os exames complementares específicos a serem realizados em cada caso. A terapia empírica não é recomendada (com poucas exceções) em pacientes com febre prolongada, uma vez que ela pode camuflar e retardar o diagnóstico e a conduta para tratar a etiologia específica. O prognóstico engloba uma mortalidade de 12-35\%, variando de acordo com a etiologia de base. O objetivo deste estudo é revisar os principais tópicos acerca da febre de origem indeterminada, trazendo aspectos históricos e científicos, nacionais e internacionais.

PALAVRAS-CHAVE: Febre de Origem Indeterminada; Febre de Origem Desconhecida; Febre prolongada

\section{REFERENCES}

1. Unger M, Karanikas G, Kerschbaumer A, Winkler S, Aletaha D. Fever of unknown origin (FUO) revised. Wien Klin Wochenschr. 2016;128(21-22):796-801.

2. Cunha BA, Lortholary $O$, Cunha $C B$. Fever of unknown origin: a clinical approach. Am J Med. 2015;128(10):1138.e1-1138.e15.

3. Lambertucci JR, Rayes AA, Nunes F, Landazuri-Palacios JE, Nobre V. Fever of undetermined origin in patients with the acquired immunodeficiency syndrome in Brazil: report on 55 cases. Rev Inst Med Trop Sao Paulo. 1999;41(1):27-32.

4. Amato Neto V. Febre de origem indeterminada. Rev Soc Bras Med Trop. 1969;3(6):323-7.

5. Bharucha $T$, Cockbain $B$, Brown M. Pyrexia of unknown origin in clinical practice. Br J Hosp Med (Lond). 2016;77(10):579-83.

6. Rigante $D$, Esposito $S$. A roadmap for fever of unknown origin in children. Int J Immunopathol Pharmacol. 2013;26(2):315-26.

7. Granato MF, Giorno EPC, Schvartsman C, Reis AG. Abscesso hepático de origem hematogênica em paciente com febre de origem indeterminada. Rev Paul Pediatr. 2012;30(3):438-42.

8. Lambertucci JR, Ávila RE, Voieta I. Febre de origem indeterminada em adultos. Rev Soc Bras Med Trop. 2005;38(6):507-13.

9. Kouijzer IJ, Bleeker-Rovers CP, Oyen WJ. FDG-PET in fever of unknown origin. Semin Nucl Med. 2013;43(5):333-9.

10. Revest M, Patrat-Delon S, Devillers A, Tattevin P, Michelet C. Contribution of 18fluoro-deoxyglucose PET/CT for the diagnosis of infectious diseases. Med Mal Infect. 2014;44(6):251-60.

11. Brown M. Pyrexia of unknown origin 90 years on: a paradigm of modern clinical medicine. Postgrad Med J. 2015;91(1082):665-9.

12. Loizidou A, Aoun M, Klastersky J. Fever of unknown origin in cancer patients. Crit Rev Oncol Hematol. 2016;101:125-30.

13. Korzeniewski K, Gawel B, Krankowska D, Wasilczuk K. Fever of unknown origin in returning travellers. Int Marit Health. 2015;66(2):77-83.

14. Marshall GS. Prolonged and recurrent fevers in children. J Infect. 2014;68(Suppl 1):S83-93.

15. Mulders-Manders CM, Simon A, Bleeker-Rovers CP. Rheumatologic diseases as the cause of fever of unknown origin. Best Pract Res Clin Rheumatol. 2016;30(5):789-801.

16. Vanderschueren $S$, Knockaert D. Tackling fever and inflammation of unknown origin: the do's and don'ts. Acta Clin Belg. 2014;69(6):412-7.

17. Kaya A, Ergul N, Kaya SY, Kilic F, Yilmaz MH, Besirli K, et al. The management and the diagnosis of fever of unknown origin. Expert Rev Anti Infect Ther. 2013;11(8):805-15.

18. Beresford RW, Gosbell IB. Pyrexia of unknown origin: causes, investigation and management. Intern Med J. 2016;46(9):1011-6.
19. Dayal $R$, Agarwal $D$. Fever in children and fever of unknown origin. Indian I Pediatr. 2016;83(1):38-43.

20. Tóth E, Speer G. Febrile conditions in rheumatology. Clin Rheumatol. 2012;31(12):1649-56.

21. Mahroum $N$, Mahagna $H$, Amital $H$. Diagnosis and classification of adult Still's disease. J Autoimmun. 2014;48-49:34-7.

22. Shi $N$, Xing $C$, Chang $X$, Dai $M$, Zhao $Y$. Pancreatic carcinoma masked as fever of unknown origin: a case report and comprehensive review of literature. Medicine (Baltimore). 2016;95(35):e4643.

23. Lambertucci JR, Gerspacher-Lara R. Febre de origem indeterminada: preceitos, pistas clínicas e exames complementares. Rev Soc Bras Med Trop. 1994;27(1):31-7

24. Petersdorf RG, Beeson PB. Fever of unexplained origin: report on 100 cases. Medicine (Baltimore) 1961;40:1-30.

25. Larson EB, Featherstone HJ, Petersdorf RG. Fever of undetermined origin: diagnosis and follow-up of 105 cases, 1970-1980. Medicine (Baltimore) 1982;61(5):269-92.

26. Knockaert DC, Vanneste LJ, Vanneste SB, Bobbaers HJ. Fever of unknown origin in the 1980s. An update of the diagnostic spectrum. Arch Intern Med. 1992;152(1):51-5.

27. De Kleijn EM, Vandenbroucke JP, van der Meer JW. Fever of unknown origin (FUO). I A. prospective multicenter study of 167 patients with FUO, using fixed epidemiologic entry criteria. The Netherlands FUO Study Group. Medicine (Baltimore) 1997;76(6):392-400.

28. Bleeker-Rovers CP, Vos Fl, Mudde AH, Dofferhoff ASM, Geus-Oei LF, Rijnders AJ, et al. A prospective multi-centre study of the value of FDGPET as part of a structured diagnostic protocol in patients with fever of unknown origin. Eur J Nucl Med Mol Imaging. 2007;34(5):694-703.

29. Arslan F, Karagöz E, Arslan BY, Mert A. An unnoticed origin of fever: periapical tooth abscess. Three case reports and literature review. Infez Med. 2016;24(1):67-70.

30. Dibble EH, Yoo DC, Noto RB. Role of PET/CT in workup of fever without a source. Radiographics. 2016;36(4):1166-77.

31. Sioka C, Assimakopoulos A, Fotopoulos A. The diagnostic role of (18)F fluorodeoxyglucose positron emission tomography in patients with fever of unknown origin. Eur J Clin Invest. 2015;45(6):601-8.

32. Basu S, Ranade R. 18-Fluoro-deoxyglucose-PET/computed tomography in infection and aseptic inflammatory disorders: value to patient management. PET Clin. 2015;10(3):431-9.

33. Besson FL, Chaumet-Riffaud P, Playe M, Noel N, Lambotte O, Goujard C, et al. Contribution of (18)F-FDG PET in the diagnostic assessment of fever of unknown origin (FUO): a stratification-based meta-analysis. Eur J Nucl Med Mol Imaging. 2016;43(10):1887-95. 